\title{
Evaluation of Cigarette Smoking Attitudes and Behaviors among Students of a State High School in Istanbul
}

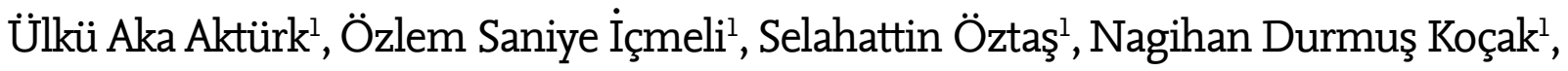 \\ Aysun Şengül ${ }^{2}$, Banu Musaffa Salepçi ${ }^{3}$, Dilek Ernam ${ }^{1}$
}

${ }^{1}$ Clinic of Chest Diseases, Süreyyapaşa Chest Diseases and Chest Surgery Training and Research Hospital, İstanbul ${ }^{2}$ Clinic of Chest Diseases, Kocaeli Derince Training and Research Hospital, Kocaeli

${ }^{3}$ Clinic of Chest Diseases, Dr. Lütfi Kırdar Kartal Training and Research Hospital, İstanbul

\begin{abstract}
Objective: We aimed to evaluate smoking habits of students, reasons of smoking and students' level of knowledge on the adverse effects of smoking in a state high school in Istanbul.

Methods: A 15-item questionnaire was administered to the students attending a state high school in İstanbul to evaluate their attitudes and behaviors towards cigarette smoking. The questionnaire was completed by each class of students at the same class period under the supervision of their teachers.

Results: The questionnaire was completed by 415 students at the respective school. While 349 students (84\%) never smoke, 66 (15.9\%) students were either current smokers or quitters. Fifty five of the students (13.2\%) were active smokers. When we looked at the reasons of smoking, they reported that $63.6 \%$ smoked cigarettes because their friends did; $47.2 \%$ smoked cigarettes due to exam-related stress; and $40 \%$ smoked cigarettes due to family problems. The rate of smoking friends in the smoker group was significantly higher than in the non-smoker group $(\mathrm{p}=0.0001)$. A logistic regression analysis showed that having smoking friends was associated with an 8 -fold increase in the risk of smoking compared to having no smoking friends.

Conclusion: The most common reasons of smoking at the school were friends who were smokers, exam-related stress and family problems. Having friends who smoke was associated with an 8-fold increase in the risk of smoking. We believe that counselling services' close engagement with family problems of students and exam-related stress issues and helping them to cope with these problems may prevent their vulnerability to toxic substances.
\end{abstract}

Keywords: Circle of friends, education planning, smoking cigarette

Received Date: 06.12.2014 Accepted Date: 28.02 .2015 Available Online Date: 28.04 .2015

Address for correspondence

Ülkü Aka Aktürk

E-mail:drulkuakturk@yahoo.com

This work is licensed under a Creative Commons Attribution-NonCommercia 4.0 International License.

DOI: $10.5152 /$ ejp.2015.02996

- Available online at www.eurasianjpulmonol.com

\section{INTRODUCTION}

Cigarette smoking is among the most commonly seen and major preventable causes of morbidity and mortality in the world, which adversely affects human health throughout lifetime $(1,2)$. It is estimated that there are overall 1.3 billion smokers across the world, and it will reach 1.7 billion by 2025 if no measures are taken.

The prevalence of smoking ranges from 15 to $60 \%$ among adolescents worldwide, and developing countries account for $80 \%$ of tobacco consumption (3-5).

According to the results of Global Youth Tobacco Survey conducted in high schools by the Ministry of Health in $2003,9.1 \%$ of all students were active smokers, and $22.3 \%$ of those students tried smoking cigarettes at least once (6). It is also known that $80 \%$ of all adult smokers started smoking before the age of 18 (7).

Social learning has a direct influence in smoking in school age children. Smoking family members or important others and peer pressure play an encouraging role $(8,9)$. Motives such as problems in the family, failures at school, undesirable socio-economic conditions, loss of self-confidence, and stress are also among parameters leading to start smoking early (10-12). 
It has been found that at least half of those who start smoking early become lifelong smokers as a result of nicotine addiction (13). The present study aimed to evaluate smoking habits of students, reasons of smoking and students' level of knowledge on the harms of smoking at a state high school located in İstanbul.

\section{METHODS}

This descriptive study was conducted within the 2012-2013 school year in a state high school on the Anatolian side of İstanbul. Following a review of the respective literature, a 15-item questionnaire was developed to identify attitude and behaviour of students towards smoking, and reflect their level of knowledge about smoking-related harms $(4,5,11)$. The questionnaire consisted of questions related to the smoking habits of students, reasons of smoking and level of knowledge about the adverse effects of smoking.

The local ethics comittee approved the protocol of this study and writtten informed consent was obtained from all students included into the study. The manager of state high school gave permission for us for applying questionnaire to the students.

The questionnaire forms were handed out to the students after a description of the study objective and reassuring students about confidentiality of personal information. The study excluded 8 students who were absent that day, and 17 students who refused to participate.

The questionnaire was administered to all students during the same class period under the supervision of teachers following appropriate planning with the school administration on a single day.

The questionnaire forms were completed anonymously. And they were collected and returned in carton boxes. The boxes were opened by the researchers, who then performed data coding and entry into the SPSS program.

\section{Statistical Analysis}

For biostatistical analysis of the study, the measures considered were described by Chi-square and Fisher exact test to compare frequency and percentages between groups. We used independent Samples t-test for comparison of mean variables with a normal distribution between the two groups.

Correlation analysis (Spearman etc.) and multivariate stepwise logistic regression analysis were performed to determine any correlation between variables, and present mathematical models of these correlations.

The limit for statistical significance was set at $p=0.05$ for interpretations. Data were analyzed using Statistical Package for the Social Sciences statistical software (SPSS, Mac Version 16, Chicago, IL, USA).

\section{RESULTS}

The study included 415 students who agreed to complete the questionnaire. Eight students who were absent that day, and 17 students who refused to participate were excluded. Of all participants, 263 (63.3\%) were female, and 152 (36.3\%) were male. The mean age was $16.41 \pm 1.05$ years. $24.3 \%$ of participants were freshmen, $26.2 \%$ were sophomores, $28.4 \%$ were juniors, and $16.8 \%$ were seniors.
Among 415 students, 66 (15.9\%) were smokers and/or quitters while the remaining 349 (84\%) never smoked. Of these 66 students, 11 (2.6\%) had quitted smoking whereas 55 (13.2\%) were active smokers. While $56.3 \%$ of smokers considered quitting, $43.7 \%$ had no such consideration.

Mean age at starting smoking was $13.62 \pm 2.49$ years. The lowest age for starting smoking was 7 years. While $57.6 \%$ of smokers reported to consume 1 to 10 cigarettes per day, 21.2\% between 10 to 20 cigarettes per day, and $21.2 \%>20$ cigarettes per day.

Among participants, $60.6 \%$ had smokers in their family. The students were asked to mark any damages to organs and systems from tobacco use. Almost $96.9 \%$ of students were aware of the adverse effects of smoking on the lungs, $81.7 \%$ on the mouth and pharyngeal cavity, $88.4 \%$ on the heart, and $88.2 \%$ harms on the vascular system while $81.2 \%$ of the students knew about the adverse effects of smoking on the skin, and $71.3 \%$ on the reproductive system. The rate of students who correctly marked all organs and systems adversely affected by smoking was $59 \%$.

The frequency and percentage distributions of all categorical variables were analysed for both smoker and non-smoker groups, and these distributions were compared using the Chi-square test. The analysis showed that the rate of smoking statistically significantly increased with increasing grade of school $(p=0.004)$. In the group of smokers, the rate of smoker friends, which was one of the reasons for starting smoking, was $91.2 \%$ vs. $49.6 \%$ in the group of non-smokers. The difference was statistically significant $(p=0.0001)$.

Nearly $57.5 \%$ of students had a history of smoking in the family. Comparison of families between smoker and non-smoker students showed that the rate of familial smoking was $70.2 \%$ for smoking students vs. $58.4 \%$ for non-smoking students, and the difference was not statistically significant $(p=0.092)$.

The rate of non-smokers who were familiar with the adverse effects of smoking on the lungs was $98.2 \%$ vs. $89.5 \%$ for smokers, and the difference was statistically very significant $(p=0.0001)$. The rate of students who knew about the harmful effects of cigarette smoking on the heart was $91.2 \%$ in non-smokers vs. $73.7 \%$ in smokers $(p=0.0001)$, with a statistically very significant difference. The rate of students who knew about the adverse effects of cigarette smoking on the mouth-pharyngeal cavity and the vascular system was higher among non-smokers compared to smokers, with a statistically significant differences ( $p=0.034$, and $p=0.019$ respectively) (Table 1$)$. Being aware of the adverse effects to particular organs and systems had a significant impact on the smoking status.

When reasons of smoking were evaluated, their smoking was related to smoker friends in $54.3 \%$ of students, to exam-related stress in $40.4 \%$, to problems in the family in $35.1 \%$, improvement in their social status in $24.6 \%$, and to smokers in their family in $21.1 \%$ of students (Table 2).

The significance of independent factors such as age, class, smoking in the circle of friends, and in the family influencing the smoking status of students were analysed using a logistic regression analysis. 


\begin{tabular}{|c|c|c|c|c|}
\hline Variables and Subgroups & & $\begin{array}{c}\text { Smokers } \\
\%\end{array}$ & $\begin{array}{c}\text { Non Smokers } \\
\%\end{array}$ & $\mathrm{p}$ value \\
\hline \multirow[t]{2}{*}{ Gender } & Female & 77.2 & 76.8 & 0.952 \\
\hline & Male & 22.8 & 23.2 & \\
\hline \multirow[t]{4}{*}{ High school grade $(1,2,3,4)$} & 1 & 8.8 & 28.2 & 0.004 \\
\hline & 2 & 29.8 & 27.0 & \\
\hline & 3 & 31.6 & 29.3 & \\
\hline & 4 & 29.8 & 15.5 & \\
\hline \multirow[t]{2}{*}{ Smoker in the family } & No & 29.8 & 41.6 & 0.092 \\
\hline & Yes & 70.2 & 58.4 & \\
\hline \multirow[t]{2}{*}{ Smoker among friends } & No & 8.8 & 50.4 & $<0.001$ \\
\hline & Yes & 91.2 & 49.6 & \\
\hline \multirow[t]{2}{*}{ Effect of smoking on lungs } & No & 10.5 & 1.8 & $<0.001$ \\
\hline & Yes & 89.5 & 98.2 & \\
\hline \multirow[t]{2}{*}{ Effect of smoking on mouth and pharengeal cavity } & No & 28.1 & 16.4 & 0.034 \\
\hline & Yes & 71.9 & 83.6 & \\
\hline \multirow[t]{2}{*}{ Effect of smoking on heart } & No & 26.3 & 8.8 & $<0.001$ \\
\hline & Yes & 73.7 & 91.2 & \\
\hline \multirow[t]{2}{*}{ Effect of smoking on vascular system } & No & 21.1 & 10.3 & 0.019 \\
\hline & Yes & 78.9 & 89.7 & \\
\hline \multirow[t]{2}{*}{ Effect of smoking on skin } & No & 28.1 & 17.9 & 0.072 \\
\hline & Yes & 71.9 & 82.1 & \\
\hline \multirow[t]{2}{*}{ Effect of smoking on reproductive organs } & No & 24.6 & 29.6 & 0.436 \\
\hline & Yes & 75.4 & 70.4 & \\
\hline \multirow[t]{2}{*}{ Effect of smoking on bladder } & No & 36.8 & 38.4 & 0.821 \\
\hline & Yes & 63.2 & 61.6 & \\
\hline
\end{tabular}

The analysis showed that the smoking in the circle of friends, and unfamiliarity with adverse effects of cigarette smoking on the heart and reproductive organs had a significant impact on the smoking status. Having smoker friends had an 8-fold increase in the risk of smoking compared to having no smoking friends. Being not known about the harmfull effects of cigarette smoking on heart had a 6.6 fold increase in the risk of smoking compared to being known about harmfull effects of cigarette smoking on heart (Table 3).

\section{DISCUSSION}

Every year 4 million people die from tobacco-related diseases in the world, and it is estimated that this number will reach 10 million by 2030. It is expected that most of these deaths will be in the developing countries (14). The World Bank Report indicates that everyday some 80000 to 100000 young people around the world become addicted to tobacco (15).

In our study, prevalence of smoking was $13.2 \%$ among students in a state high school. The smoking in the circle of friends, and unfamiliarity with adverse effects of cigarette smoking on the heart and reproductive organs had a significant impact on the smoking status. Having smoker friends had an 8-fold increase in the risk of smoking compared to having no smoking friends. Being not known about the harmfull effects of cigarette smoking on heart had a 6.6 fold increase in the risk of smoking compared to being known about harmfull effects of cigarette smoking on heart.

Several studies performed among primary school and high school students in Turkey between 1988 and 2009 reported that the prevalence of cigarette smoking ranged from 18 to $43 \%$, and that cigarette smoking was more common among boys than girls (16-25). Studies in Italy and the United States of America (USA) found that use of cigarettes was more common among female students $(26,27)$.

At national level, the prevalence of smoking among adolescents (15 to 18 age group) was $30 \%$ according to the 1988 PIAR survey (28).

The present study including 415 students in a state high school in İstanbul found that the prevalence of smoking was $13.2 \%$, which is lower compared to other surveys in the country. Of all students, $2.6 \%$ were quitters. We believe that higher rate of female students in the school (63.3\%) might have contributed to our lower smoking prevalence compared to other studies. 


\begin{tabular}{|c|c|c|}
\hline & $\mathbf{n}$ & $\%$ \\
\hline Exam-related stress & 23 & 40.4 \\
\hline Smoking friends & 31 & 54.3 \\
\hline Smoker (s) in the family & 12 & 21.1 \\
\hline Problems in the family & 20 & 35.1 \\
\hline Social status & 14 & 24.6 \\
\hline $\begin{array}{l}\text { Other (curiosity, wannabe, maintaining } \\
\text { current body weight, pleasure) }\end{array}$ & 29 & 50.9 \\
\hline
\end{tabular}

Table 3. The effect of independent factors on smoking status using a logistic regression analysis

\begin{tabular}{|l|c|c|c|c|c|}
\hline & S.E. & Sig. & Exp (B) & 95\% C.I. for Exp (B) \\
\cline { 5 - 6 } Age & .16 & .007 & 1.56 & 1.13 & 2.16 \\
Circle of friends & .49 & .001 & 8.10 & 3.07 & 21.37 \\
Effect of smoking on heart & .51 & .001 & .15 & .055 & 0.41 \\
$\begin{array}{l}\text { Effect of smoking on } \\
\text { reproductive system }\end{array}$ & .48 & .007 & 3.71 & 1.43 & 9.58 \\
\hline
\end{tabular}

Cl:Confidence interval; Exp: exponentiated logistic coefficients; OR: odds ratio; S.E.: standart error; Sig: significance ( $p$ value)

According to a PIAR survery, $63 \%$ of smokers in our country started smoking before the age of 18 (28). The likelihood of starting smoking ranged from 43 to $50 \%$ at the ages of 11 to 14 among secondary education students in Turkey $(16,17,26,29,30)$. The mean age of smoking initiation was 12.3 years among adolescents in the United States (31). Studies showed that students were introduced to smoking and had their first smoking experience during the transition period from primary school to secondary school $(16,17,26,29,30)$. In the present study, the mean age of smoking initiation was $13.62 \pm 2.49$ years, which is consistent with the current literature. The youngest age at starting smoking was 7 years.

Many surveys have already proven the encouraging role of smoker parents on the teenagers who start smoking. The frequency of smoking in young people who have smoking parents or siblings is higher (26, 32-34). Another important factor affecting smoking among students is being in a group of friends who are smokers. In the presence of smoking friends, desire to fit in or peer pressure makes it easier for a child to start smoking.

Studies by Ergüder et al. (35) across Turkey, Keskinoğlu et al. (36) in İzmir, and Ünlü et al. (37) in Afyon found that circle of friends and siblings were a significant factor in starting smoking. Keskinoğlu et al. (36) indicated that almost half of the smoking students reported stress as a cause of smoking. A study by Arbak et al. (21) also reported that stress was the most significant factor for continuing smoking among students.

In a study by Göksel et al. (20) in the province of İzmir, a strong correlation was found between presence of a smoking sibling and smoking status of students whereas there was no relationship between smoking parents and lower level of education and smoking status of students. The same study also indicated that friends were the most encouraging factor in starting smoking.

In the present study, reasons of smoking reported were related to presence of smoking friends in $54.3 \%$, to exam-related stress in $40.4 \%$, to familial problems in $35.1 \%$, to have improvement in social status in $24.6 \%$, and to a smoking family in $21.1 \%$ of smokers. A comparison of percentages and frequencies of variables between smokers and non-smokers showed that the rate of smoking friends was significantly higher in smoker group than in non-smoker group. Smoking in the circle of friends was a significant factor, and it even resulted in a 8-fold increase in the risk of smoking. However, unlike some other studies, we found no statistically significant relationship between familial history of smoking and smoking status of students.

Similar to other studies, the amount of cigarette smoking per day was high among high school students in our study. We found that $57.6 \%$ of smokers smoked half a package of cigarettes per day. Göksel et al. (20) reported that $74.9 \%$ of students consumed half a package of cigarettes per day.

In a study by Çelik et al. (22) in Manisa, $95.5 \%$ of students were aware of the harmful effects of smoking, with $95.8 \%$ knowing its association with lung cancer, and $82.4 \%$ being familiar with adverse effects of passive smoking on the health. The level of knowledge about the harms of active and passive smoking was higher in non-smoker group than in smoker group. Keskinoğlu et al. (36) found that awareness of adverse effects of smoking by majority of students had no impact on the prevalence of smoking.

In our study majority of students was well-informed about harmful effects of smoking on the health while there was a lack of information about the adverse effects on the body organs. Most of them were aware that cigarette smoking was harmful to the lungs and pharyngeal cavity whereas less number of students were familiar with the harms to the heart, vascular system, skin, reproductive organs and bladder. Furthermore, awareness level of adverse effects of smoking on the lungs and heart was significantly lower in the smoker group compared to non-smoker group $(p=0.0001)$.

In a study by Çelik et al. (22) $77.7 \%$ of students reported their will to quit smoking while the rate was $63.7 \%$ in a study by Yüksel et al. (38). In our study, $56.3 \%$ of students reported that they wanted to quit smoking. This rate is lower compared to the rates reported by other studies in Turkey.

The major limitations of our study are including only one school and small sample size. Therefore it can not be generalizable. Other limitations of this study included the lack of questions which might have evaluated students' level of knowledge about passive smoking and socioeconomic status of the family. Another limitation was supervision by school teachers during administration of the questionnaire due to restricted number of researchers. Although students were reaasured about confidentiality of personal information and the questionnaire forms were anonymous, they might have provided misinformation due to presence of their teachers. Ideally the questionnaire should have been administered by an independent supervisor other than their school personnel. 


\section{CONCLUSION}

In conclusion, we found that circle of friends was very important in starting smoking among young people. We also found that lack of information about the adverse effects of smoking was significantly higher in smoker group. Therefore, friend groups are very important in struggle against smoking in children. It is highly recommended that parents should become friends with their children and keep them away from group of smoking friends. In addition to legal measures taken to prevent young people to start smoking, educational programs with a broader scope focusing on harms of smoking and its adverse effects on human life should be planned in schools.

Ethics Committee Approval: Ethics committee approval was received for this study from the local ethics committee of Süreyyapaşa Chest Disease and Thoracic Surgery Training and Research Hospital.

Informed Consent: Consent form was obtained from students who participated in this study.

Peer-review: Externally peer-reviewed.

Author contributions: Concept - Ü.A.A., Ö.S.I., S.Ö., N.D.K., A.S., B.M.S., D.E.; Design - Ü.A.A., Ö.S.I., S.Ö., N.D.K., A.S., B.M.S., D.E.; Supervision - Ü.A.A., Ö.S.İ., S.Ö., N.D.K., A.S., B.M.S., D.E.; Materials - Ü.A.A., Ö.S.I., S.Ö.; Data Collection and/ or Processing - Ü.A.A., S.Ö., A.S.; Analysis and/or Interpretation - Ü.A.A., N.D.K., A.S.; Literature Search - A.S., S.Ö.; Writing - Ü.A.A.; Critical Reviews - B.M.S., D.E.

Conflict of Interest: No conflict of interest was declared by the authors.

Financial Disclosure: The authors declared that this study has received no financial support

\section{REFERENCES}

1. California Environmental Protection Acency' Healthy effects of exposure to environmental tobacco smoke' Final Report. California Environmental Protection Acency Office Of Environmental Health Hazard Assesment, 1997.

2. Hofhuis W, Jongste JC, Merkus PJF. Adverse health effects of postnatal tobacco smoke exposure on children. Arc Dis Child 2003; 88: 1086-90.

3. Centers for Disease Control and Prevention (CDC). Tobacco use among high school students- United States, 1997. MMWR Morb Mortal Wkly Rep 1998; 47: 229-33. [CrossRef]

4. Currie C, Hurrelmann K, Settertobulte W, Smith R, Todd J. Health behaviour in school aged children. A WHO cross-national study. International report. WHO health policy for children and adolescents series No 1. 2000.

5. Piko PF, Luszczynska A, Gibbons FX, Tekozel M. A culture-based study of personal and social influences of adolescent smoking. Eur J Public Health 2005; 15: 393-8. [CrossRef]

6. Sağlık Bakanlığı Madde Bağımlılığı Şube Müdürlüğü. Türkiye Küresel Gençlik Tütün Araştırması 2003.

7. Williams GC, Cox EM, Kouides R, Deci EL. Presenting the facts about smoking to adolescents: effects of an autonomy-supportive style. Arch Pediatr Adolesc Med 1999; 153: 959-64. [CrossRef]

8. Alexander C, Piazza M, Mekos D, Valente T. Pers, schools and adolescent cigarette smoking. J Adolesc Health 2001; 29: 22-30. [CrossRef]

9. Buller DB, Borland R, Woodall WG, Hall JR, Burris-Woodall P, Voeks JH. Understanding factors that influence smoking uptake. Tob Control 2003; 12: 16-25. [CrossRef]

10. Bonewitz N. Nicotine addiction. Prim Care Clin Office Prac 1999; 26: 61131. [CrossRef]

11. Wang MQ. Social environment influences on adolescents' smoking progression. Am J Health Behav 2001; 25: 418-25. [CrossRef]

12. De Vires H. Socio-economic differences in smoking. Dutch adolescents beliefs and bahaviour. Soc Sci Med 1195; 41: 419-24.
13. Burt RD, Peterson AV. Smoking cessation among high school seniors. Prev Med 1998; 27: 319-27. [CrossRef]

14. World Health Report 1999. Geneva, WHO.

15. World Bank. Curbing The Epidemic: Governments and the Economics of Tobacco Control. 1999. Washington, World Bank.

16. Kocabaş A. Orta dereceli okul öğrencilerinde sigara içme alışkanlığı. Ankara Tıp Mecmuası 1988; 41: 9-22.

17. Saltık A, Yılmaz T, Yorulmaz F, Keleş F, Dindar İ, Turan N. Edirne merkezinde 5100 orta-lise öğrencisinde sigara içme davranış ve Spielberger testi ile ölçülen kaygı düzeyinin incelenmesi. Ege Tıp Dergisi 1992; 31: 53-9.

18. Güraksın A, Ezmaci T, Inandı T, Vançelik S, Tufan Y. Erzurumda orta ve lise öğrencilerinde sigara prevelansı. AÜTD 1998; 30: 89-93.

19. Demirhan H, Bostancı M, Zincir, Özen I. Denizli Tavas ilçe merkezinde öğrenim görmekte olan ortaöğrenim öğrencilerinde sigara, alkol ve uçucu madde kullanımı. Sağlık ve Toplum 2001; 11: 74-80.

20. Göksel T, Cirit M, Bayındır Ü. Factors affecting smoking behavior in high school students in İzmir. Turk Thorac J 2001; 2: 49-53.

21. Arbak P, Erdem F, Karacan Ö, Özdemir Ö. Smoking habits in high-school students in Düzce. Eurasian J Pulmonol 2000; 2: 17-21.

22. Çelik P, Esen A, Yorgancıoğlu A, Sen F, Topçu F. Manisa ilinde lise öğrencileinin sigaraya karşı tutumları. Turk Thorac J 2000; 1: 61-6.

23. Ögel K, Tamar D, Evren C, Çakmak D. Lise gençleri arasında sigara alkol ve madde kullanım yaygınlığı. Türk Psikiyatri Dergisi 2001; 12: 47-52.

24. Alikaşifoğlu M, Erginöz E, Ercan O, Uysal O, Kaymak-Albayrak D, Ilter O. Cigarette smoking among Turkish high school students. J Adolesc Health 2002; 30: 7-8.

25. Sezer RE, Öztürk ŞZ, Bilgin N. Elazığ'da lise ve dengi okul üçüncü sınıf öğrencilerinde sigara içme durumu-1989. Fırat Üniv Derg 1990; 5: 121-33.

26. Coogan PF, Adams M, Geller AC, Brooks D, Miller DR, Lew RA, et al. Factors associated with smoking among children and adolescents in Connecticut. Am J Prev Med 1998; 15: 17-24. [CrossRef]

27. Gaeta G, Del Castello E, Cuomo S, EfFuso L, Boccalatte A. Familial and friends who smoke: influence on adolescents. G Ital Cardiol 1998; 28: 259-66.

28. PIAR. Sigara alışkanlıkları ve sigara ile mücadele kampanyası kamuoyu araştırması raporu 1988. Ankara, TC. Sağlık Bakanlığı.

29. Tümerdem $Y$, Ayhan B, Emekli U. İstanbul kentinde öğrenim gençliğinde sigara içme olayı etkinliklerinin araştırılması. Eurasian J Pulmonol 1986; 412-6.

30. Everett SA, Husten CG, Warren CW, Crossette L, Sharp D. Trends in tobacco use among high school students in the United States, 1991-1995. J Sch Health 1998; 68: 137-40. [CrossRef]

31. Harrel JS, Bangdiwala SI, Deng S, Webb JP, Bradley C. Smoking initiation in youth: the roles of gender, race, socioeconomics and developmental status. J Adolesc Health 1998; 23: 271-9. [CrossRef]

32. Flay BR, Hu FB, Richardson J. Psychosocial predictors of different stages of cigarette smoking among high school students. Prev Med 1998; 27: 9-18. [CrossRef]

33. Skinner WF, Massey JL, Krohn MD, Lauer RM. Social influences and constraints on the initiation and cessation of adolescent tobacco use. J Behav Med 1985; 8: 353-75. [CrossRef]

34. Collins LM, Sussman S, Rauch JM, Dent CW, Johnson CA, Hansen WB et al. Psychosocial predictors of young adolescents cigarette smoking: a sixteen-month, three wave longitudinal study. J Appl Social Psychol 1987; 17: 554-73. [CrossRef]

35. Ergüder T, Soydal T, Uğurlu M, Çakır B, Warren CW. Küresel Gençlik Tütün Araştırması Türkiye. Sağlık Bakanlığı Madde Bağımlılı̆̆ı Şube Müdürlüğü 2003.

36. Keskinoğlu P, Karakuş N, Pıçakçıefe M, Giray H, Bilgiç N, Kılıç B. İzmir'de lise öğrencilerinde sigara içme sıklığı ve içicilik davranışı üzerine sosyal öğrenmenin etkisi. Turk Thorac J 2006; 7: 190-5.

37. Ünlü M, Orman A, Şen TA, Doğan N, Tuncer GZ. Factors affecting the cigarette smoking habits among students in Afyon-Turkey. Turkiye Klinikleri Arch Lung 2004; 1: 15-9.

38. Yüksel S, Cücen Z. Enquiries into cigarette smoking habits of university students. Turk Thorac J 2001; 13: 169-73. [CrossRef] 